\title{
Reflections on a 38-year career in public health advocacy: 10 pieces of advice to early career researchers and advocates
}

\author{
Simon Chapman ${ }^{a, b}$ \\ a Sydney School of Public Health, University of Sydney, NSW, Australia \\ b Corresponding author: simon.chapman@sydney.edu.au
}

\section{Article history}

\section{Publication date: March 2015}

Citation: Chapman S. Reflections on a 38year career in public health advocacy: 10 pieces of advice to early career researchers and advocates. Public Health Res Pract. 2015;25(2):e2521514. doi: http://dx.doi. org/10.17061/phrp2521514

\section{Key points}

- Media attention on a public health issue is often more effective than private advocacy in winning policy change

- Advocacy must be evidence based, clear and concrete

- Speak out publicly, study the media and be available to speak at all times

- Use 'killer (attention-grabbing) facts', but place them in the context of a values system; care about what you are advocating for

- Use real people to illustrate your message

- Use social media

- Be patient; grow a 'rhinoceros hide'

\section{Abstract}

There are many important principles and lessons that public health researchers and advocates who hope to influence policy and practice need to consider. In this paper, I set out what I consider to be 10 of the most fundamental of these. Together, these focus on the importance of preserving public confidence in the evidence base underscoring public policy; being clear and concrete about the policy reforms you support; emphasising the values on which policy is based; understanding the structure, conventions and subtextual features of news reporting; developing 'killer facts' with 'earworm' potential; appreciating that the advocacy process leading to policy change almost always takes a long time; and growing a rhinoceros hide to assist in the inevitable attacks you will face.

\section{Introduction}

In the late 1970s, I worked with others to try to have the actor Paul Hogan removed from Winfield cigarette advertising. ${ }^{1}$ It was, and remains, the most successful tobacco advertising campaign in Australian history. Hogan had immense appeal with teenagers. This made his role a clear breach of the voluntary code of advertising self-regulation that was then operating. ${ }^{2}$

Our private, polite efforts to get something done through the complaints system were virtually ignored until we went public through the media. Ten-thousand watt lights tend to concentrate the attention of those with responsibility to act. And so act they finally did. Hogan was removed 18 months after we started complaining. ${ }^{1}$

I learnt a big lesson very quickly: sunlight makes a very strong antiseptic for malodorous health policy. And there is no sunlight stronger than getting an issue major media attention.

I soon discovered that there were remarkably few analytical histories of how either large or small public health advocacy campaigns and policy battles had been won or lost. So I set out to change that by writing books ${ }^{3-6}$ and dozens of papers on the process I had often been part of.

Below are 10 key lessons I've learnt in public health advocacy. There are many more, but these 10 are absolutely critical. 


\section{Lesson 1: always respect evidence, and if the evidence changes, so should you}

Evidence must always be the granite bedrock of all public health advocacy. Evidence evolves through stages. It starts with hypothesis-generating claims and observations, and moves through to the gold standards of large-scale cohort epidemiology and randomised controlled trials in real-world settings.

As evidence mounts, things that once looked true or effective can sometimes turn out not to be. We have seen the cancer screening and dietary areas slowly and sometimes reluctantly coming to terms with the fact that past doctrines are being eroded by the tide of incoming evidence.

Careers are often built on lifetime commitment to particular phases of evidence. But if the evidence changes, it is absolutely critical for public trust in the integrity of public health that we acknowledge the facts have changed and, accordingly, that we have changed our minds too.

It is important to note that the internet has changed forever the politics of expertise. For a long time, expertise was exercised in forums that were largely inaccessible to the public and handed down to the populace as advisories and campaigns. But today, access to unprecedented amounts of research and the ability to disseminate it to millions has opened up a kind of anarchy of 'expertise' that poses a massive threat to continuing public confidence in public health.

Two illustrations of the advance of junk and lowquality science are the resilience and influence of climate change denialism, and the current efforts by e-cigarette interest groups to claim that e-cigarettes have revolutionary potential to make smoking history.

The interest groups behind these two major issues are succeeding in building momentum that may spread to challenge decades of public health and safety legislation.

Public health practitioners today face unprecedented challenges to preserve and strengthen public and political confidence in the evidence base for public health policy. Challenging and confronting low-grade and self-interested evidence from such forces will never be more important. It is the very worst time to retreat into unnoticed and inconsequential debates within the walls of academia.

\section{Lesson 2: be clear and concrete}

\section{about what you want to change or support}

People often say, "tobacco control has done so well in changing policy to reduce smoking, what lessons do you have for our issue?" My first question to them is always what is it they want to achieve. Almost invariably they answer with a goal, such as reducing obesity or problem drinking. Sometimes they talk about an important but obtuse value like "reducing health inequalities" or "getting greater attention to the social determinants of health".

Talking about complex and worthy abstractions is important and meaningful to small groups of specialists. But this is not how ordinary people talk. Public health is often mired in language with little meaning outside the cognoscenti. A 'policy' to most people is something you get in the mail once a year from your insurance company. Policy change may be your goal, but policy will not change unless you make it crystal clear what you want from policy makers. That's what we did with plain packaging for cigarettes: every square centimetre of the pack, the fonts, the colours, was specified following research with target groups. It could not have been more focused.

Take, for example, alcohol advertising controls. A colleague, Andrea Fogarty, interviewed 28 of Australia's leading alcohol policy researchers, who offered generalisations about the need for 'controls'. But once asked about precisely what sort of controls they wanted introduced, there was little consensus. There was no clear, sharp message for policy makers and the public to consider. $^{7}$

I try to focus colleagues by asking them to pull their attention into the foreground. What precisely needs to happen to reach the broad health goals so easily articulated? Precisely what policies, legislation or funding would they like the government to put in their Christmas stocking next year? Once that's decided, the meat and potatoes work of strategic, policy-relevant research can occur along with the precision 'bombing' of false arguments from those opposed to change.

\section{Lesson 3: "It's better to be looked over, than overlooked" (Mae West)}

I've never seen sense in applying for grants, doing years of work, and then parking the results in paywalled journals where only other academics can access it. The attitude that expertise carries no responsibility to ensure evidence reaches the public and policy makers is bizarre.

A few years ago, a National Health and Medical Research Council project I led with Wayne Hall (Professorial Fellow at the University of Queensland) interviewed 35 Australian public health researchers who had been voted by their peers as Australia's most influential researchers working in six fields. Large majorities agreed or strongly agreed that researchers had a duty to influence policy and to draw public attention to their work. ${ }^{8}$

As researchers, we undertake research and systematically review it to provide evidence to lever policy and practice change or defend existing policies and practices. But there is only a small number of people who 
have the power to effect change or defend good policies. The most important of these are politicians. And guess what? They don't read research journals! ${ }^{9}$

During nearly 40 years, I have had countless occasions to speak to prime ministers, health ministers, their cabinet colleagues, and thousands of influential people in every walk of life. I've done this as they lay in bed, ate breakfast, drove their cars, sat in their living rooms and relaxed in their shorts and T-shirts on holidays. By contrast, I have had face-to-face meetings with politicians perhaps 100 times in my life. Let me explain.

When I first met former health minister Nicola Roxon, we shook hands and I said I didn't think we had met. She replied that she felt she had known me half her life. This could have only meant that she had heard me and read of my work in the news media. She was one of the highly influential people I had spoken to, often without knowing. She was already very receptive to various issues that my colleagues and I had been emphasising for years. If you avoid the media, very few people will ever learn about your work and what needs to be done. You and your research are far less likely to be influential.

If you care about making a difference, you will put aside the regrettably still-prevalent attitude in some institutions that you should not "dally with the Delilah of the press". ${ }^{10}$

\section{Lesson 4: study the media}

If you want to be a potent media advocate for evidence and policy change, you need to know how the media works and how you can best be part of it. Many of you may have taken days to prepare a 10-15 minute presentation. The lucky ones will speak to 300 or so in a plenary, most will get only 40-50 people in a breakout session.

But a few will be tapped by journalists at the conference. If you get interviewed for radio or TV news, your message might be heard by hundreds of thousands of people - sometimes millions. To maximise these unparalleled opportunities, you need to understand the medium and programs on which you appear. On Australian television news, the time anyone gets to speak in a 90-second item averages 7.2 seconds, with an interquartile range of 4.8-9.2 seconds. ${ }^{11}$ Knowing that, you can plan precisely what you are going to say and emphasise.

When print journalists request comments (and this increasingly will happen via email), I try to drop everything and send a selection of one- or two-sentence options. This makes journalists' jobs easier and they appreciate that.

Again, knowing about length restrictions, you can shape a message with Exocet precision. Try to make every quote you send a potential 'breakout box' rather than some anodyne, forgettable 'memo to the public'. This will mark you as 'good talent', and they'll contact you again and again.

Above all, be accessible. This should be so obvious. For seven years, I was a regular guest on Adam Spencer's Sydney ABC breakfast program with a listening audience of half a million. I was curious about this and emailed him for this presentation. He told me immediately, "because you always answer your phone. The number of people we rang and they missed out because they didn't realise tomorrow morning was their one shot was incredibly frustrating".

\section{Lesson 5: use 'killer facts'}

Every year, people are exposed to thousands of facts, claims and narratives about hundreds of health issues. Much of it is like informational wallpaper, forgotten moments later, contradicted by competing claims and washed away on the tide of tomorrow's more arresting news. Some issues rise above the rest and compel political action. Many plod along unchanging and others sink without trace.

A basic goal in advocacy is to have your definition of the issue in a policy debate become the dominant, topof-mind way people - and especially politicians - think about that issue.

Killer facts ${ }^{12}$ are like musical earworms: once they're inside your head, it is difficult to get them out. They tend to kill off competing definitions of the issue. If they employ powerful and repeatable analogies, before and after comparisons, and humour if appropriate, this can really help. I heard one recently: "Public health is about saving lives ... a million at a time".

Here are some examples:

- The US has 13.5 times Australia's population, 5.9 times Australia's rate of gun ownership and 305 times Australia's gun homicide rate. So more guns make a country safer?

- In the 18 years before Australia's 1996 gun law reforms, there were 13 mass shootings (five or more deaths, not including the perpetrator). There have been precisely none in the 19 years since.

- For four of the past five years, quad bikes have been the leading cause of non-intentional injury death on Australian farms. This is unique internationally, as in all other Western nations, tractors continue to be the leading cause of injury deaths.

Every advocate, for every issue, needs to stock up on killer facts. Plan to use at least one of them every time you are interviewed.

\section{Lesson 6: values are everything}

As stated, facts and evidence are the bedrock of public health advocacy. But unless people care about an issue, they are highly unlikely to pay attention to it, let alone act on it. Caring about something is always a necessary, but not a sufficient, precondition for support and action.

Public health issues often feature in the news because they richly illustrate narratives about values: mini dramas and secular parables about adversity and the solutions needed. These include the humane imperative to reduce 
early death and suffering; the injustice of inequitable distribution of disease and access to services; and stories about those who put financial gain ahead of population health.

So after you've filled your kit bag with killer facts, you need to then take an inventory of the values that make these facts even more compelling. For example, killer facts about tobacco industry expansion in nations with low literacy are powerful because they evoke eons of examples of the Pied Piper mythology: wolves in sheep's clothing who lead the vulnerable into illness and death. Your facts and evidence should be anchored firmly to the values that will make them resonate with what George Lakoff calls 'moral politics'. ${ }^{13}$

You also need to take an inventory of your vulnerability to opponents framing your position as embodying negative values, and then seek to strategically reframe these as positives. The 'nanny state'14 epithet, for example, can be easily reframed positively by pointing out all the benefits caused by regulations and standards that we all take for granted. As I stood in my narrow hotel shower recess this morning, I whispered a silent "thank you" to the public health nannies who ensured via enforceable safety glass standards that if I slipped, the glass would not shatter and cut me to ribbons.

\section{Lesson 7: experts are fine, but they are not 'a living thing"}

A journalist once said the above to me ${ }^{15}$, and l've never forgotten it: people who live with the diseases we try to prevent appear more in the news media than experts or politicians. ${ }^{11}$

When an expert speaks, we may admire their coherence, grasp of the issues and ability to simplify complexity. But if a person suffering a problem speaks and does the same, it can be doubly powerful. Ordinary people can make amazing advocates, and we should work with them far more. They bring a compelling authenticity to an issue.

\section{Lesson 8: use social media. A lot}

The internet has utterly revolutionised our lives. And utterly transformed advocacy. There are simply massive global participation rates in social media. Anyone in public health who is not part of this is the equivalent of a scholar in the Gutenberg era who declined to show interest in the potential of books.

I'm a heavy Twitter user. If you're like I used to be and thought Twitter sounded like some sort of time-wasting indulgence for vapid twits, you may have already pulled the shutters down. But look what you are missing out on. Let me give you three examples.

The paper I published that has the most internet downloads looked at the impact on multiple killings and total gun deaths of the post-Port Arthur gun law reforms. ${ }^{16}$
It has had nearly 124000 downloads since 1996, with 86000 in December 2012 after I tweeted the link following the US Sandy Hook massacre. It has been cited 109 times.

A preprint of my much-tweeted paper on the nocebo effect and wind farm health complaints ${ }^{17}$ is the most downloaded item in the entire University of Sydney eScholarhip repository and featured in a video that has been viewed 4.02 million times: www.youtube.com/ watch?v=O2hO4_UEe-4\&feature=youtu.be\&a

My most retweeted tweet was one I sent after Treasurer Joe Hockey's public remark about wind turbines being an ugly blight on the landscape: twitter.com/SimonChapman6/ status/472132442032054272/photo/1. It has had 2894 retweets, so given the exponential nature of retweets, probably well over a million people have seen it.

\section{Lesson 9: successful advocacy takes time}

Much public health research focuses on proximal associations ${ }^{18}$ between interventions and outcomes weeks, months, sometimes a year or two. But advocacy's dividends often take decades to deliver. ${ }^{19}$

Smoking was first banned on public buses and trains in NSW in 1976. It took until 2006 - 30 years later - before such bans extended to working environments where the problem was worst, and where, in a totally rational world, smoke-free areas should have started. Even today, high roller rooms in some casinos allow smoking: it's apparently a little known fact that second-hand smoke from wealthy gamblers is unique in not posing health risks to others. ${ }^{20}$

\section{Lesson 10: grow a rhinoceros hide}

Finally, unless you are an advocate for an utterly uncontroversial policy (I was going to say 'for a mother's milk policy', but of course even breastfeeding gets attacked in some contexts), as soon as your work threatens an industry or ideological cabal you will be attacked, sometimes unrelentingly and viciously.

I've been called a veritable sewer of names on social media, often by anonymous trolls and tobacco industryfunded bloggers. I've been attacked in the coward's castle of parliament under privilege, and on the Alan Jones radio program (and received a written apology and legal costs paid), falsely accused of being an undeclared paid advocate for the wind and pharmaceutical industries, and sent white feathers each year on the anniversary of the 1996 Port Arthur gun massacre. My university administration is regularly deluged with orchestrated complaints, yet l've had nothing but total support from my university and colleagues.

But in all this nastiness, I take deep satisfaction and pride in having worked with colleagues who are lifetime friends to help make Australia's smoking rates the lowest in the world. ${ }^{6}$ 
Many of you are doing fabulous work to achieve similar goals in your areas. Clinicians are thanked every day by grateful patients and relatives for their skills in saving lives and limbs. In public health, we don't have people saying to us "I've not been killed or injured because of your advocacy for road injury reduction policy" or "I've not got diabetes, and I put it down to you". But our achievements can be seen in many areas of declining incidence of disease and injury. We do fantastically important work and I've been blessed to be part of it for 40 years. Thank you for all you do.

\section{Acknowledgements}

This article was originally presented as a plenary address to the 43rd Annual Conference of the Public Health Association of Australia, Perth, 17 September 2014.

\section{Competing interests}

None declared

\section{References}

1. Chapman S. A David and Goliath story: tobacco advertising and self-regulation in Australia. Br Med J. 1980;281(6249):1187-90.

2. Chapman S, Mackay B. Good for the goose, good for the gander: complaints and judgements about smoking and anti-smoking advertisements under advertising self regulation. Media Information Australia. 1984;31:47-55.

3. Chapman S, Lupton D. The fight for public health: principles and practice of media advocacy. London: British Medical Journal Books; 1994.

4. Chapman S. Over our dead bodies: Port Arthur and Australia's fight for gun control. Sydney: Pluto Press; 1998.

5. Chapman S. Public health advocacy and tobacco control: making smoking history. Oxford: Blackwell Publishing; 2007.

6. Chapman S, Freeman B. Removing the emperor's clothes: Australia's plain tobacco packaging. Sydney: Sydney University Press; 2014.

7. Fogarty AS, Chapman S. What should be done about policy on alcohol pricing and promotions? Australian experts' views of policy priorities: a qualitative interview study. BMC Public Health. 2013;13:610.

8. Chapman S, Haynes A, Derrick G, Sturk H, Hall WD, St George A. Reaching "an audience that you would never dream of speaking to": influential public health researchers' views on the role of news media in influencing policy and public understanding. J Health Commun. 2014;19(2):260-73.
9. Haynes AS, Derrick GE, Redman S, Hall WD, Gillespie JA, Chapman S, et al. Identifying trustworthy experts: how do policymakers find and assess public health researchers worth consulting or collaborating with? PloS One. 2012;7(3):e32665.

10. Osler WR. Aequanimitas with other addresses to medical students, nurses and practitioners of medicine. Philadelphia: P. Blakiston's Son \& Co; 1904.

11. Chapman S, Holding SJ, Ellerm J, Heenan RC Fogarty AS, Imison M, et al. The content and structure of Australian television reportage on health and medicine, 2005-2009: parameters to guide health workers. Med J Aust. 2009;191(11-12):620-4.

12. Bowen S, Zwi AB, Sainsbury P, Whitehead M. Killer facts, policies and other influences: what evidence triggered early childhood intervention policies in Australia? Evid Policy. 2009;5(1):5-32.

13. Lakoff G. Don't think of an elephant! Know your values and frame the debate. Vermont: Chelsea Green Publishing; 2004.

14. Daube M, Stafford J, Bond L. No need for nanny. Tob Control. 2008;17(6):426-7.

15. Chapman S, McCarthy S, Lupton D. Very good punterspeak: how journalists frame the news on public health. Sydney: University of Sydney eScholarship Repository; 1995 [cited 2015 Jan 27]. Available from: ses.library.usyd. edu.au//bitstream/2123/10759/2/PUNTERSPEAK.pdf .

16. Chapman S, Alpers P, Agho K, Jones M. Australia's 1996 gun law reforms: faster falls in firearm deaths, firearm suicides, and a decade without mass shootings. Inj Prev. 2006;12(6):365-72.

17. Chapman S, St George A, Waller K, Cakic V. The pattern of complaints about Australian wind farms does not match the establishment and distribution of turbines: support for the psychogenic, 'communicated disease' hypothesis. PloS One. 2013;8(10):e76584.

18. McMichael AJ. Prisoners of the proximate: loosening the constraints on epidemiology in an age of change. Am J Epidemiol. 1999;149(10):887-97.

19. Chapman S. Unravelling gossamer with boxing gloves: problems in explaining the decline in smoking. Br Med J. 1993;307(6901):429-32.

20. Chapman S. How santa and the tooth fairy collaborated to allow smoking at Barangaroo. Sydney Morning Herald. 2013 Nov 29 [cited 2015 Jan 27]. Available from: www.smh.com.au/comment/how-santa-and-the-toothfairy-collaborated-to-allow-smoking-at-barangaroo20131128-2ye0y.html

\section{Copyright: (c)(3) (2)}

(C) 2015 Chapman. This article is licensed under the Creative Commons Attribution-NonCommercial-ShareAlike 4.0 International Licence, which allows others to redistribute, adapt and share this work non-commercially provided they attribute the work and any adapted version of it is distributed under the same Creative Commons licence terms. See: www.creativecommons.org/licenses/by-nc-sa/4.0/ 